\title{
The Model of Berasanan Culture and its Implementation in Learning to Improve Students' Motivation
}

\author{
Sri Septiani, Muhammad Kristiawan and Happy Fitria \\ Universitas PGRI Palembang, Universitas Bengkulu \\ e-mail: muhammadkristiawan@unib.ac.id
}

(Received: February 4-2019; revised: May 16 29-2019; published: May 31-2019)

\begin{abstract}
This study aimed at finding out how the cultural model of berasanan and its implementation in civics learning, as well as knowing how the cultural model of berasanan can increase learning motivation in Secondary School class VII. A South Indralaya. The research was classroom action research (CAR) which done in two cycles. The first cycle was conducted three times and the second cycle was held twice. The subjects of this study were 29 students. The steps of each cycle include planning, action, observation, evaluation and reflection. The data were collected by using test, questionnaire, observation sheet, and documentation methods. The results of the study showed that students' learning motivation experienced an increase in the learning process from cycle one to the second cycle. Students' attention during the learning process, cooperation in working on group assignments, students' participation, and courage to think showed that learning activities are increased. Negative activities of students' learning civics were asking permission to go to the bathroom. This change showed that the interest and enthusiasm of students' learning was increased and learning was more effective and enjoyable. Achievement of students' learning outcomes also showed an increase, students' learning from the first cycle of $75 \%$ increased to $86.2 \%$ in the second cycle.
\end{abstract}

Keywords: Model of Berasanan Culture; Instruction; Students’ Learning Motivation

\section{INTRODUCTION}

Education is an effort to shape changes, both in mindset and behavior of students (Cooley \& Larson, 2018; Puente-Díaz \& Cavazos-Arroyo, 2017; Stamboulis \& Barlas, 2014; Tang, Werner, \& Karwowski, 2016). The student who has a mindset and good behavior leads to progress to further improve and advance the nation and state. PKn (Citizenship Education) Learning in Secondary School is given to have students actively in learning, the emergence of mutual cooperation between students, students can apply the subject in daily life, and what is not less important is learning can be fun for students. Citizenship Education gave the center attention to the formation of citizens who understand and are able to exercise their rights and obligations in order to become intelligent, skilled, and characteristic Indonesian citizens mandated by Pancasila and the 1945 Constitution.

The observations on September $2^{\text {nd }}, 2013$ during the learning process in the classroom showed that students were more likely to be passive as well as reciprocal interesting interactions between students and teachers did not appear. Students are lazy in learning, for example when given assignments often students do not do well, the homework that students should do at home is still done at school. In addition, students often come out of the class with the reason to go to the restroom, students seem very lazy and are not interested in the classroom. The results of the 
38| Jurnal Ilmiah Ilmu Administrasi Publik: Jurnal Pemikiran dan Penelitian Administrasi Publik

Volume 9 Number 1, January - June 2019. Page 37-56

tests and evaluations that have been carried out are also relatively low. The material provided by the teacher is not well understood by students, collaboration between students is also lacking because the learning pattern is more teacher centric with one-way interaction. It can be said that students' learning motivation were low. The low learning motivation of students is suspected because the teacher has not developed a learning pattern that can involve students actively interacting, and the teacher dominates in the learning process. Students do not receive refreshments during the learning process because the method used by the teacher is monotonous. Props or media that help attract students in learning are also rarely used by teachers.

Teachers need to develop creativity to improve students' learning motivation. Motivation of students in learning will determine the learning outcomes. Isnawati \& Setyorini (2012) state that learning motivation has a more effective contribution to students' learning achievement. The same thing was conveyed by Chiang, Yang, \& Hwang (2014) who stated that the most influential factor in students' learning achievement was motivation to learn. Thus, student learning motivation, both intrinsic or extrinsic, is the most important determinant for learning achievement. Other opinion from Ismail (2013) who stated that the level of student motivation was high but at a moderate level. The level of self-learning occupies a moderate level, but still lower than extrinsic motivation. This shows that students are not fully prepared in the context of independent learning and are still dependent on the teacher as a source of information and educational resources.

Herzberg (2017) stated that how strong a motivation someone will determine much on the quality of the behavior he displays, both in the context of learning, working, and in other lives. Mihrez \& Thoyib (2015) also states that motivation is one of the factors that influence the effectiveness of student learning activities. Students want to do learning activities because they are motivated. So, high learning motivation will create more effective and quality students' learning activities. Students will behave actively if they have high motivation in learning. The activity of students in the learning process will ultimately affect the achievement of the expected learning outcomes. Low learning motivation will have an impact on learning outcomes.

Given the importance of learning motivation for students, the teacher needs to find a solution. Motivation of students who are low in learning must be improved. The learning process that will be carried out is made to be interesting, fun and make students excited. In this regard, the researchers attempted to improve students' learning motivation by applying a culture of style models that were lifted from the culture of the Ogan Ilir community in the learning process. The culture model is a process of activities in the procession before the proposal for marriage of the Ogan Ilir community. Ridhon (2011) says that berasanan in Malay language means to deliberate to unite two families into one extended family. The purpose of this event is to determine what is asked by the girl and what will be given by the man. The development of a cultural model of temperance in learning can be described by the syntax as follows.

Students form groups of 4-6 people. Students then discuss the same or different material between groups through group discussions. Two delegates from one group berasanan to other groups to discuss and ask for the results of discussion groups of friends; so do these other groups at the same time. Next, the teacher facilitates discussion, then provides reinforcement. 
This research was conducted because according to Ginting's research (2016) that the application of the Teams Games Tournaments (TGT) cooperative learning model can increase the motivation of students who are highly motivated from $16.67 \%$ with an average achievement of $43.99 \%$ from the learning motivation indicator at the initial observation to $91.67 \%$ with an average achievement of $80.99 \%$ of the indicators of student learning motivation at the end of cycle II. In addition, according to Malawi \& Juwarti (2016) the application of cooperative learning makes students more interested in the learning process, where students not only learn but also play games, which requires better student achievement compared from conventional models (Novelti, Ramadhan, Ermanto, \& Agustina, 2018).

The application of a culture-based model is cooperative learning that is expected to provide a new atmosphere and refreshment for students in pleasant learning in addition to planting love for their own culture. Students will be more enthusiastic in learning and local wisdom can be instilled in students. Thus this study focuses on the berasanan culture model and Its implementation in PKn learning to increase civics learning motivation in the material of the meanings of the independence proclamation and the first constitution of Secondary School class VII. A South Indralaya.

Motivation needs to be done, so the students' learning interests can be increased. Motivation is the overall driving force in students that gives rise to learning activities, guarantees the continuity of teaching and learning activities, and gives direction to learning activities to achieve goals (Stamboulis \& Barlas, 2014). Another motivational theory was developed by (Healy \& Healy, 2016) whose essence is that humans have five hierarchical needs, (1) psychological needs, such as hunger, thirst, rest and sex; (2) safety needs, not only in the physical sense, but also in the mental, psychological and intellectual sense; (3) love needs; (4) self-esteem needs, which are generally reflected in various status symbols; and (5) selfactualization, the availability of opportunities for someone to develop the potential contained within him to change into real abilities. Another point of view, McClelland (Sudrajat, 2008) stated about the theory of the need to achieve achievement or Need for Acievement (N.Ach) contains different motivations, according to the strength of individual needs for achievement. The condition of students in a class will show different learning motivations, according to the strength of students' needs for achievement. Factors that influence student learning in general, are divided into two categories, internal and external factors. Both of these factors influence each other's individual learning processes thus determining the quality of Mallajareng's learning outcomes (2013). Nur (2005) states that teachers every day can use cooperative learning which is a practical classroom technique that can help students master the learning material, ranging from basic skills to complex problem solving. This cooperative learning, students work in small groups helping each other, heterogeneous members, men, women, students with different ethnic backgrounds, disabled students (if any), students with high, average and low learning outcomes

Berasanan culture is to deliberate to unite two families into one extended family. This moody atmosphere is usually full of rhyme, followed by the groom giving cash money from the bride's family as well as handing money to smoke (spending money) to prepare for the wedding procession later.

In this study, applying the cultural model of learning in Civics learning as described below. The teacher divides students into 6 groups. Each group member puts a number on the arm. Each group discusses different questions based on the problems the teacher has prepared 
40 Jurnal Ilmiah Ilmu Administrasi Publik: Jurnal Pemikiran dan Penelitian Administrasi Publik

Volume 9 Number 1, January - June 2019. Page 37-56

related to the learning objectives to be achieved. Students discuss in groups and students also study the source book to answer questions. After each group completes the task, each group must obtain 1 result of discussion from another group. Each group sends one envoy to another group and each group delegate who will go to another group must submit the rhyme as well, the rhyme has been prepared by the teacher.

\section{METHOD}

This research was conducted using classroom action research. Thus, the procedure for implementing it follows the basic principles of action research. This activity is carried out in two cycles, each cycle consisting of four main steps, planning, implementing actions, observing and evaluating and reflecting. The four main interrelated steps in the implementation are often referred to as one cycle (Sanjaya, 2016). The implementation was carried out in the Civics learning process which was followed by students of class VII A of South Indralaya Middle School 2 in 2013/2014 totaling 29 people. The first cycle consists of 3 meetings and the second cycle consists of 2 meetings. In addition to researchers, this study involved 2 Integrated Social Studies teachers at South Middle School as observers. Observer I is Dra. Sulasmi and observer II are Budiman, S.Pd. Overall activities in this study are observation sheets to observe changes in student behavior during the implementation. The observed aspects are (1) students' attention during learning, (2) collaboration in group discussions, (3) participation (4) courage to think. Observation uses a scale of 1 until 4 with category $4=$ very good, $3=\operatorname{good}, 2=$ enough, and $1=$ less. Especially regarding student activity scores, the following interpretation tables are used.

\section{Table 1.}

\begin{tabular}{lll} 
Interpretation of Observation Results \\
\hline Number & $\begin{array}{c}\text { Average } \\
\text { Activity Score }\end{array}$ & Category \\
\hline 1 & $1,0-1,4$ & Less \\
2 & $1,5-2,4$ & Enough \\
3 & $2,5-3,4$ & Well \\
4 & $3,5-4,0$ & Very good \\
\hline
\end{tabular}

Tests to measure students' learning outcomes after experiencing action. Questionnaires to get student responses regarding understanding of Civics subject matter being studied, opinions of students discussing in learning, responsibility for assignments given, and student opinions on successful beliefs in learning Civics. Documentation to collect data about student activities and learning processes during the course of action. Documentation using documents 1) results of student work such as; results of assignments, questionnaires for students in the first cycle, final test results for cycle I, II) filling in instruments, such as; Fill in the observation sheet, teacher notes, and 3) photos of activities in Cycle I and Cycle II. The research data were analyzed using descriptive analysis techniques through the process of tabulation, selection, description, display, 
and interpretation of data, while the questionnaire and and tests used simple statistical data analysis using percentages.

\section{RESULT AND DISCUSSION}

This research was carried out for 2 cycles, starting in the $1^{\text {st }}$ week of September $2^{\text {nd }}$ week of December 2013. The model of culture of Berasanan and its implementation in Civics learning can be demonstrated in the learning process carried out at each meeting in the first cycle and second cycle. The following is a description of the implementation of a cultural model in Civics learning in the first and second meetings of cycle I

The first meeting of the first cycle was held on October 14, 2013, Monday, the $6^{\text {th }}$ and $7^{\text {th }}$ lesson hours. Its basic competence was 2.1 about the meaning of the proclamation of independence. The learning objectives that will be achieved in this first meeting are 3. Students are expected to describe the characteristics of the struggle before and after 1908, students can explain the suffering of the Indonesian people during the colonial period, and students can explain the factors that triggered the Indonesian people to fight for their independence.

Learning begins with apperception preparing classes in learning including attendance of student attendance, check class cleanliness and others. The teacher motivates students by conducting an assessment of student learning readiness by giving questions about the material to be taught. The teacher then informs the competencies to be achieved.

The core activity, the teacher explained in general the importance of the struggle of the Indonesian people towards the seconds of the proclamation of independence. The teacher then said that PKN learning would implement a culture-based model. The teacher divides students into 6 groups. Each group member puts a number on the arm. Each group discusses different questions based on the problems prepared by the teacher relating to the learning objectives 1-3 at the meeting I. Students discuss in groups and students also study the source book to answer questions. After each group completes the task, each group must obtain 1 result of discussion from another group. Each group sends one envoy to another group and each group delegate who will enter another group must submit a rhyme and will be rewarded with a rhyme as well. The teacher has prepared rhyme. The rhyme I delivered by the group delegates to other groups as the host reads the following.

Alangkah lebat si buah jambu, rontoklah semua diguyur hujan. Izinkan kami datang

bertamu, karna da hal penting tuk disampaikan. Then the host group responded to the

rhyme with the following rhymes II. Matahari ke barat tandalah petang, domba berlari

masuk ke pagar. Silahkan masuk selamat datang, pintu rumah sudah terbuka lebar.

After returning to each other the rhyme and then each messenger asks for the results of the discussion by noting in the notebook, which will later be copied on the answer sheet. Each group, through its member representatives, reports in writing the results of the discussion in front of the class and continues by asking for responses from the class, guided by the teacher. The presentation was closed with a rhyme III (prepared by the teacher), which was jointly delivered by group members who advanced in front of the class. The rhyme reads as follows "Berseri-seri wajah mualaf, sungguh elok si Cenderawasih. Maafkan atas salah dan khilaf, cukup sekian dan terima kasih". After students return to their seats, the teacher then asks students about things they have not yet known. The teacher also provides reinforcement, 
42 Jurnal Ilmiah Ilmu Administrasi Publik: Jurnal Pemikiran dan Penelitian Administrasi Publik Volume 9 Number 1, January - June 2019. Page 37-56

rectifies mis-understandings through question and answer activities and together with the teacher's students then concludes. Students with teacher guidance conclude the results of the discussion. The teacher gives a written test as feedback. Follow-up by giving the task of reading and understanding the material to prepare for the discussion the following week.

This first meeting class condition is still not well conditioned, students still look confused. The class seemed noisy and noisy, but the students seemed enthusiastic to take part in the learning process that took place. Many students are still not active in group discussions. The allocation of time for discussion and the process of Berasanan lasts longer than the specified time. This is because students still do not fully understand the cultural model of being applied. Second, students of class VII A are also still not familiar with group discussions in learning. In this first meeting students who have negative activities can be seen among them a student who is cool to draw and does not participate in the learning process, in group discussion activities. There were also two students who asked permission to leave the room.

The second meeting was held on October 21, 2013, Monday, the $6^{\text {th }}$ and $7^{\text {th }}$ lesson hours. Basic competency is 2.1. about the Meaning of the Proclamation. The learning objectives that will be achieved are explaining the meaning of independence for a nation and explaining the importance of inheriting the spirit of the proclamation.

Learning begins with apperception, the teacher prepares learning (absenteeism, student neatness, class hygiene, etc). The teacher explores students' learning readiness by giving questions about the material that has been taught to provide motivation. The teacher then provides information about the competencies to be achieved.

The core activity, the teacher explains the material about the meaning of independence for the Indonesian nation and the importance of the spirit of the proclamation. The teacher then explained about the learning scenario of applying the cultural model that will be implemented, followed by group division (into 6 groups, consisting of 4-5 students in one group). The group condition was the same as meeting I. The teacher put the envelope containing assignments in front of the class, and henceforth in an orderly manner the group representatives take the envelope according to their group number. Each group member puts a number on the sleeve, for division of tasks. Each group discusses different questions about problems related to learning objectives 4-5, which the teacher has prepared.

Students discuss in groups and students also study the source book to answer questions. After each group completes the task, each group must obtain 1 result of discussion from another group. Each group sends one envoy to another group and each group delegate who will enter another group must submit a rhyme and will be rewarded with a rhyme as well. The teacher has prepared rhyme. Rhyme I, which was delivered by the group's envoy to another group as the host, which reads the following "Alangkah lebat si buah jambu, rontoklah semua diguyur hujan. Izinkan kami datang bertamu, karena ada hal penting tuk disampaikan". Then the host group returned the rhyme with the poem II, which reads the following "Matahari ke barat tandalah petang, domba berlari masuk ke pagar. Silahkan masuk selamat datang, pintu rumah sudah terbuka lebar".

After returning to each other the rhyme and then each messenger asks for the results of the discussion by noting in the notebook, which will later be copied on the answer sheet. Each group, through its member representatives, reports verbally and in writing the results of the 
discussion in front of the class and continues by asking for responses from the class, guided by the teacher. The presentation was closed with a rhyme III (prepared by the teacher), which was jointly delivered by group members who advanced in front of the class. The rhyme reads as follows "Berseri-seri wajah mualaf, sungguh elok si Cenderawasih. Maafkan atas salah dan khilaf, cukup sekian dan terima kasih".

The teacher asks questions about things that have not been known by students. The teacher and students ask questions to correct misunderstandings, provide reinforcement and conclusions. Student with teacher conclude the results of the discussion. The teacher gives a written test as feedback. Follow-up by giving the task of reading and understanding the material to prepare for the discussion the following week

The results of observations of student activities in several aspects, using a score of 1 s.d. 4 , for the first meeting, the following is presented.

\section{Table 2.}

List of Observation Results of Student Activities in Cycle I

\begin{tabular}{|c|c|c|c|c|}
\hline Number & Name of Student & $\begin{array}{l}\text { Total } \\
\text { Score }\end{array}$ & $\begin{array}{c}\text { Average } \\
\text { Category } \\
\text { Score }\end{array}$ & Category \\
\hline 1 & Afrizal & 11 & 2.8 & Well \\
\hline 2 & Agung Anugra & 10 & 2.5 & Well \\
\hline 3 & Aini Rosdiana & 12 & 3.0 & Well \\
\hline 4 & Aldian. M & 12 & 3.0 & Well \\
\hline 5 & Beben & 12 & 3.0 & Well \\
\hline 6 & Deni .P & 9 & 2.3 & Enough \\
\hline 7 & Desti Nabaiti & 12 & 3.0 & Well \\
\hline 8 & Diah Kartika Sari & 12 & 3.0 & Well \\
\hline 9 & Eka Nur Meylia & 12 & 3.0 & Well \\
\hline 10 & Fadli & 10 & 2.5 & Well \\
\hline 11 & Fahri Akbar & 12 & 3.0 & Well \\
\hline 12 & Hernita & 10 & 2.5 & Well \\
\hline 13 & Irka Haros. M & 12 & 3.0 & Well \\
\hline 14 & Ivan Setiawan & 10 & 2.5 & Well \\
\hline 15 & Kartini & 10 & 2.5 & Well \\
\hline 16 & Lusiana & 12 & 3.0 & Well \\
\hline 17 & Maryati & 10 & 2.5 & Well \\
\hline 18 & M. Syahrul Gunawan & 10 & 2.5 & Well \\
\hline 19 & M. Yogi Pratama & 10 & 2.5 & Well \\
\hline 20 & M. Zarkasih & 10 & 2.5 & Well \\
\hline 21 & Muhammad Kadafi & 9 & 2.3 & Enough \\
\hline 22 & Nur Ahmad & 10 & 2.5 & Well \\
\hline 23 & Paisal Basri & 9 & 2.3 & Enough \\
\hline 24 & Pini Oktaria. P & 12 & 3.0 & Well \\
\hline 25 & Raditya Nugraha & 10 & 2.3 & Enough \\
\hline
\end{tabular}


$44 \mid$ Jurnal Ilmiah Ilmu Administrasi Publik: Jurnal Pemikiran dan Penelitian Administrasi Publik Volume 9 Number 1, January - June 2019. Page 37-56

\begin{tabular}{lllll}
26 & Rama .A & 10 & 2.5 & Well \\
27 & Riska Andriani & 12 & 3.0 & Well \\
28 & Riski Diana Putri & 12 & 3.0 & Well \\
29 & Sindi Nova & 12 & 3.0 & Well \\
\hline
\end{tabular}

The table above shows that the activities of students from 29 VII. A students at the first meeting of the first cycle were 25 students had good learning activities and 4 students had sufficient learning activities in PKn lessons. A diagram of student activities is presented in the following figure.

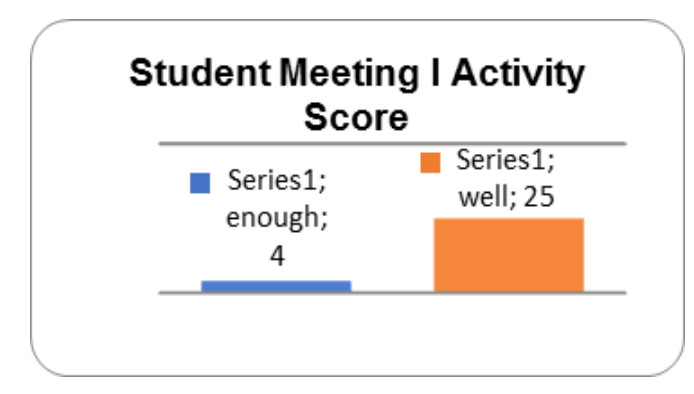

\section{Figure 1. Activity Score for Student Meeting I}

The diagram shows the activity scores and their percentages described below.

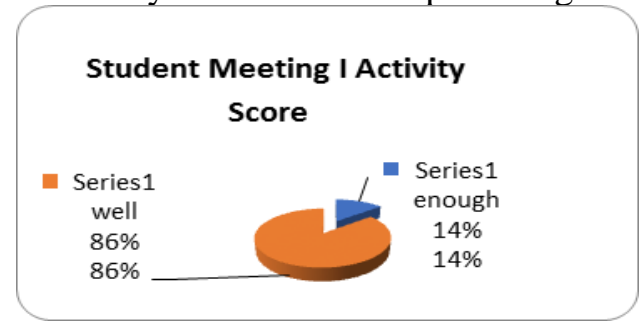

Figure 2. Activity Scores of Meeting I and Percentage Students

On the diagram it can be seen that student learning activities show "good" by $86 \%$ and student learning activities that show "enough" by $14 \%$. The average score of observations at meeting I per aspect is presented in the following tables and diagrams.

\section{Table 3.}

\section{Average Observation Score in Cycle I}

\begin{tabular}{lcl}
\hline \multicolumn{1}{c}{ Average } & $\begin{array}{c}\text { aspects of } \\
\text { category }\end{array}$ & scores \\
\hline Student attention during learning & 2,59 & well \\
ooperation in carrying out tasks & 2,86 & well \\
Participation & 2,62 & well \\
Courage argues & 2,72 & well \\
\hline
\end{tabular}




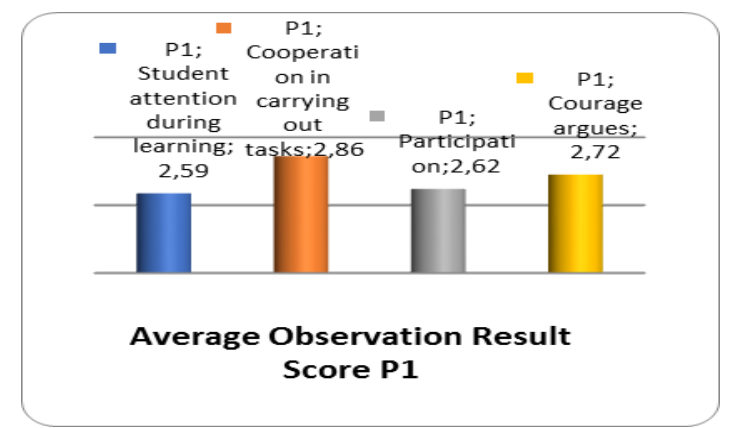

Figure 3. Average Diagram of Scoring Results of Meeting I Meeting

In the table and diagram above shows that students' learning activities are good (value> 2.5) for each component assessed. The most prominent learning activities are teamwork $(2.86 \%)$. The next learning activity is courage to think (2.72\%), then participating learning activities (2.62\%), then the activities of student attention during the learning process $(2.59 \%)$.

The following are included tables and diagrams that describe student learning activities during cycle I.

\section{Table 4.}

Student Learning Activities in Cycle I

\begin{tabular}{clcccc}
\hline \multirow{2}{*}{ Number } & \multirow{2}{*}{ Observation Aspects } & \multicolumn{4}{c}{$\begin{array}{c}\text { Scores of Each Meeting } \\
\text { and Average Score }\end{array}$} \\
\cline { 3 - 6 } & & P1 & P2 & P3 & S1 \\
\hline 1 & Student attention during learning & 2.59 & 2.83 & 3.07 & 2.83 \\
2 & Cooperation in carrying out tasks & 2.8621 & 3.34 & 3.38 & 3.20 \\
3 & Participation & 2.62 & 2.90 & 3.10 & 2.87 \\
4 & Courage argues & 2.72 & 2.79 & 3.34 & 2.95 \\
\hline
\end{tabular}

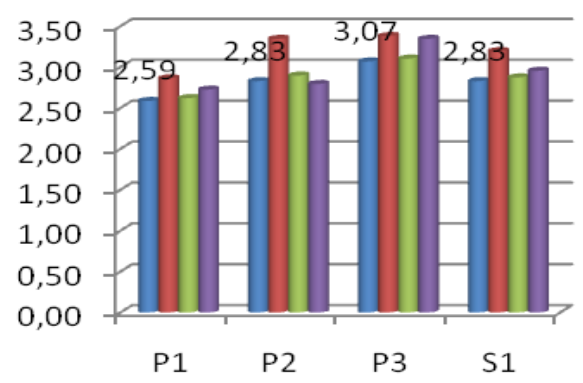

Student attention during learning

- Cooperation in carrying out tasks

- Participation

Courage argues

Figure 4. Student Learning Activities in Cycle I 
46 Jurnal Ilmiah Ilmu Administrasi Publik: Jurnal Pemikiran dan Penelitian Administrasi Publik Volume 9 Number 1, January - June 2019. Page 37-56

In the tables and diagrams above, it shows that in Cycle I the highest to lowest student learning activities are cooperation in carrying out tasks (3.20), courage to think (2.95), participation (2.87), and attention students during learning (2.83). Values in the cycle indicate that learning activities that occur are good learning activities, because they range in value from 2.5 to 3.4 .

Test results at the end of the first cycle, after being analyzed from the percentage of student learning completeness, with the KKM 73 value shown in the following tables and diagrams.

\section{Table 5.}

Student Learning Outcomes at the End of Cycle I

\begin{tabular}{lcrrr}
\hline Number & Value & $\begin{array}{c}\text { the Number } \\
\text { of student }\end{array}$ & $\begin{array}{c}\text { Completed } \\
\text { Students }\end{array}$ & $\begin{array}{c}\text { Not } \\
\text { Complete }\end{array}$ \\
\hline 1 & $<54$ & - & - & - \\
2 & $55-64$ & - & - & - \\
3 & $65-74$ & 7 & 7 & 7 \\
4 & $75-84$ & 14 & 14 & \\
5 & $85-94$ & 7 & 7 & \\
6 & $95-$ & 1 & 1 & \\
total & 100 & 29 & 22 & 7 \\
\multicolumn{2}{l}{$\%$ Completeness } & $\mathbf{1 0 0}$ & $\mathbf{7 5 . 9}$ & $\mathbf{2 4 , 1}$ \\
\hline
\end{tabular}

The learning outcomes of class VIIA students in the first cycle showed 7 people (24.1\%) were not completed and 22 people $(75.9 \%)$ were completed from 29 students. KKM (Minimum Completion Criteria) class VII is 73 . For students who are thoroughly given enrichment, in the form of in-depth material related to the subject learned from the source book or article. For students who are not complete, they are given a remedial on the test questions that have been done before, on the wrong number. Learning outcomes diagram can be seen in the following picture. 


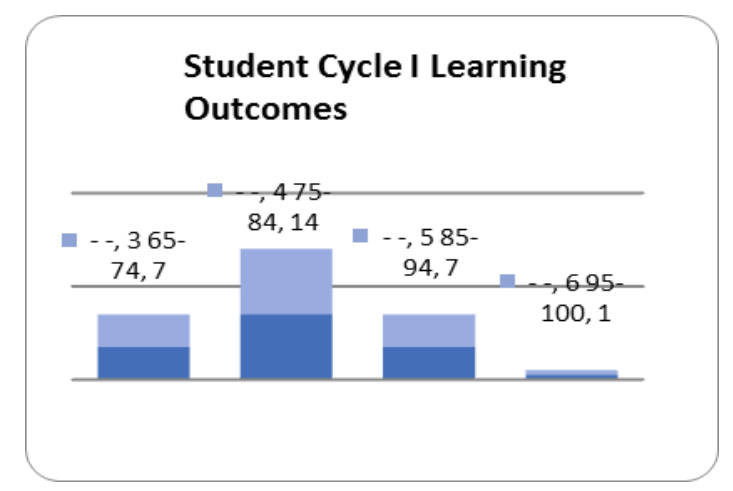

Figure 5. Diagram of Student Cycle I Learning Outcomes

Data obtained based on student questionnaires at the end of cycle I is presented below.

Table 6.

Questionnaire for Class VII A Students

\begin{tabular}{|c|c|c|c|c|c|c|c|}
\hline \multirow[t]{2}{*}{ number } & \multirow[t]{2}{*}{ statement } & \multicolumn{5}{|c|}{$\begin{array}{c}\text { total signs of tick each } \\
\text { statement }\end{array}$} & \multirow{2}{*}{$\begin{array}{c}\text { Total } \\
\text { student }\end{array}$} \\
\hline & & STS & TS & $\mathbf{R R}$ & $\mathbf{S}$ & SS & \\
\hline 1 & $\begin{array}{l}\text { Happy PKn lessons with } \\
\text { discuss in groups }\end{array}$ & & & & 2 & 27 & 29 \\
\hline 2 & $\begin{array}{l}\text { Understand each subject matter } \\
\text { the teacher delivered. }\end{array}$ & & & 1 & 6 & 22 & 29 \\
\hline 3 & Communicate with friends & 1 & 1 & 1 & 17 & 9 & 29 \\
\hline 4 & Don't feel embarrassed to ask & & & 2 & 21 & 6 & 29 \\
\hline 5 & Convinced success in PPKn & & & 5 & 9 & 15 & 29 \\
\hline 6 & $\begin{array}{l}\text { Related material } \\
\text { with what is learned }\end{array}$ & & & & 16 & 13 & 29 \\
\hline 7 & $\begin{array}{l}\text { Many who are not yet known must } \\
\text { continue to try } \\
\text { Satisfied if the learning outcomes are }\end{array}$ & & & & 14 & 15 & 29 \\
\hline 8 & $\begin{array}{l}\text { good } \\
\text { Sure the subject matter is well }\end{array}$ & & & & 6 & 23 & 29 \\
\hline 9 & mastered & & & 2 & 21 & 6 & 29 \\
\hline 10 & $\begin{array}{l}\text { If given a task with } \\
\text { full of responsibility }\end{array}$ & & & 1 & 4 & 24 & 29 \\
\hline & total & 1 & 1 & 12 & 116 & 160 & 290 \\
\hline & Percentage $(\%)$ & 0.34 & 0.34 & 4.14 & 40 & 55.17 & 100 \\
\hline
\end{tabular}

In the table above shows that students declare Strongly Agree (SS) on the statement given at (55\%), Agree (S) (40\%), Doubtful (R) (4.14\%), Disagree (TS) (0.34\%), and Strongly Disagree (STS) (0.34\%). Based on the table data above, it can also be said that the VII A class students during the first cycle enjoyed the PKn lessons and showed their 
48 Jurnal Ilmiah Ilmu Administrasi Publik: Jurnal Pemikiran dan Penelitian Administrasi Publik Volume 9 Number 1, January - June 2019. Page 37-56

enthusiasm for learning in the PKn subjects. This is shown in the SS and S statement values in the questionnaire that reached $(95 \%), \mathrm{R}(4.14 \%)$ and the rest TS and STS did not reach (1\%) Cycle II The following is shown in the table and Student Activity Score diagram in Cycle II.

\section{Table 7.}

Student Activity Scores in Cycle II

\begin{tabular}{llll}
\hline \multirow{1}{*}{\multicolumn{1}{c}{ Observation Aspect }} & \multicolumn{3}{c}{$\begin{array}{c}\text { Scores for each } \\
\text { meeting and } \\
\text { average score }\end{array}$} \\
\cline { 2 - 4 } & P4 & P5 & S2 \\
\hline Student attention during learning & 3.21 & 3.55 & 3.38 \\
Cooperation in carrying out tasks & 3.34 & 3.34 & 3.34 \\
Participation & 3.14 & 3.31 & 3.22 \\
Courage argues & 2.90 & 3.38 & 3.14 \\
\hline
\end{tabular}

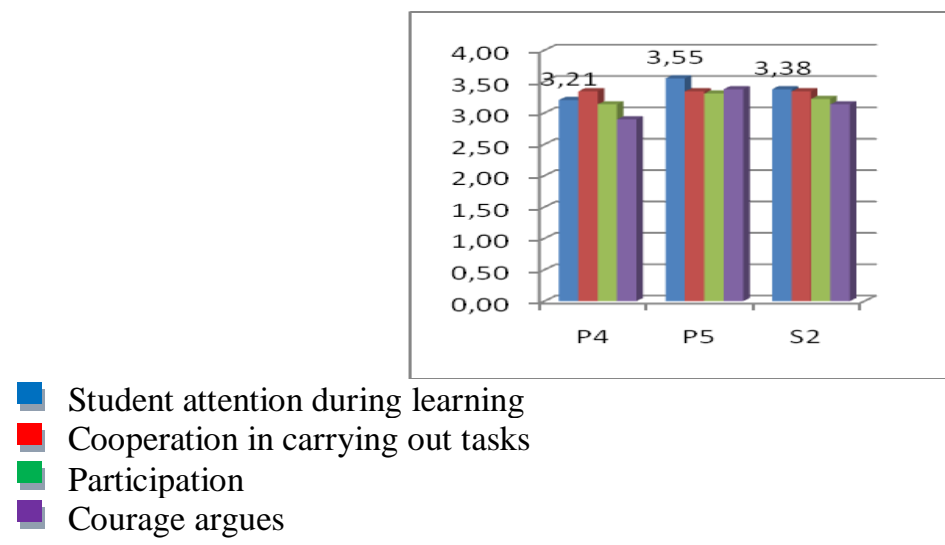

Figure 6. Score Diagram of Student Learning Activities in Cycle II

In the table and diagram above shows that the score of student learning activities from the highest to the lowest is the attention of students during learning (3.38), cooperation in carrying out tasks (3.34), participation (3.22), and courage to think (3.14). The value of the activity cycle II score is good for each component of activity, because it ranges in the range of values (2.5 3.4).

Test results at the end of the second cycle, after being analyzed from the percentage of student learning completeness, with the KKM 73 value shown in the following tables and diagrams. 


\section{Table 8.}

Student Learning Outcomes at the End of Cycle I

\begin{tabular}{llrrr}
\hline Number & Valuw & The number of students & Complete & Not completed \\
\hline 1 & $<54$ & - & - & - \\
2 & $55-64$ & - & - & - \\
3 & $65-74$ & 4 & - & 4 \\
4 & $75-84$ & 16 & 16 & - \\
5 & $85-94$ & 9 & 9 & - \\
6 & $95-100$ & - & - & - \\
\multicolumn{2}{l}{$\%$} & 29 & 25 & 4 \\
\multicolumn{2}{l}{ Completeness } & 100 & 86,2 & 13,8 \\
\hline
\end{tabular}

The learning outcomes of class VIIA students in the second cycle showed that 4 people (13.4\%) were not completed and 25 people (86.2\%) were completed from 29 students. KKM (Minimum Completion Criteria) class VII is 73. For students who are thoroughly given enrichment, in the form of in-depth material related to the subject learned from the source book or article. For students who are not complete, they are given a remedial on the test questions that have been done before, on the wrong number. Learning outcomes diagram as follows.

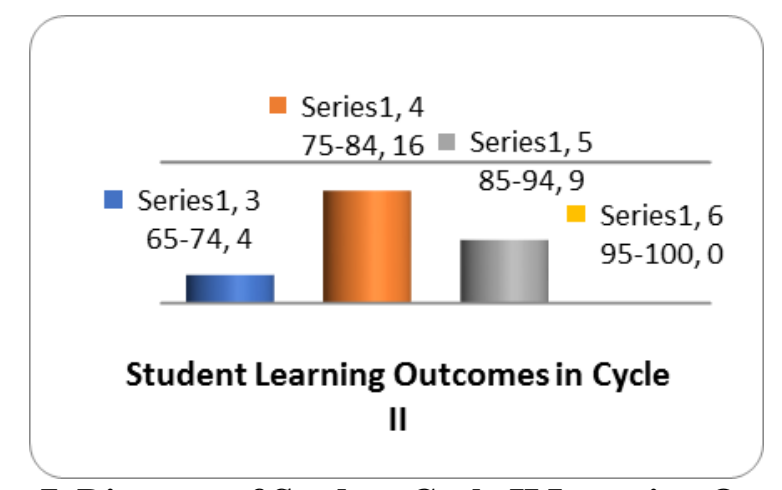

Figure 7. Diagram of Student Cycle II Learning Outcomes

The Berasan cultural model is included in cooperative learning because students work in small groups that help each other, with heterogeneous members (Fajri, Yoesoef, \& Nur, 2017). The elements of cooperative learning (Dewi \& Arifin, 2016), such as sharing the same tasks and responsibilities, sharing skills in learning, and having the same goals in the group, also exist in the cultural models that are applied in this study. Research on cooperative learning, to improve student learning motivation has been done by Utari, (2018) mentioning that the application of TGT cooperative learning can increase the motivation of students who are highly motivated from $16.67 \%$ with an average achievement of $43.99 \%$ from the learning motivation indicator at the initial observation to $91,67 \%$ with an average achievement of $80.99 \%$ of the indicators of student learning motivation at the end of cycle II. In addition, according to Malawi and Juwarti (2016) that the application of cooperative learning with the make a match model makes students 
50| Jurnal Ilmiah Ilmu Administrasi Publik: Jurnal Pemikiran dan Penelitian Administrasi Publik Volume 9 Number 1, January - June 2019. Page 37-56

more interested in the learning process, where students not only learn but also play games, which requires better student achievement compared to conventional models

The study of this cultural model when associated with the results of previous studies above, it can be said that the development of models (types) of cooperative learning learning, including cultural models, can increase student motivation in the process of teaching and learning activities because students can learn through things pleasant things, in which there are game functions, and challenges that are more varied than conventional boring learning.

Through cooperative learning with cultural models, students can acquire skills to cooperate, courage to think, participate in learning, and increase their attention during learning. Students can also develop their creativity in dancing as a cultural heritage. The teacher as the facilitator still has important functions. This is because students are not fully prepared in the context of independent learning and are still dependent on the teacher as a source of information and educational resources (Vibulphol, 2016). Harmonious and communicative relationships between teachers and students will support an effective learning atmosphere.

The results of the above research indicate that the cultural model of temperament not only affects learning motivation, but also will have a positive impact on student achievement / learning outcomes. State that learning motivation has a more effective contribution to student learning achievement (Amaliyah, Akib, \& Tambe, 2015; Idzhar, 2016; Isnawati \& Setyorini, 2012; Niswaty \& Darwis, 2015). Also states that the most influential factor in student learning achievement is motivation to learn (Kamaluddin, Haerul, Akib, \& Salam, 2018; Saggaf, Nasriyah, Salam, \& Wirawan, 2018; Saggaf, Salam, \& Rifka, 2017; Salam, Akib, \& Daraba, 2018). So, student learning motivation, both intrinsic or extrinsic, is the most important factor in learning achievement.

The first meeting of the class condition was still not well-conditioned, students still looked confused. The class seemed noisy and noisy, but the students seemed enthusiastic to take part in the learning process that took place. Many students are still not active in group discussions. The allocation of time for discussion and the process of Berasanan lasts longer than the specified time. This is because students still do not fully understand the cultural model of being applied. Second, students of class VII A are also still not familiar with group discussions in learning. In this first meeting students who have negative activities can be seen among them a student who is cool to draw and does not participate in the learning process, namely in group discussion activities. The students who asked permission to leave the room there were 2 students.

The second meeting, the class condition was quite good. The class still looks noisy, but the familiar learning atmosphere begins to emerge. The majority of students have begun to memorize the rhyme, so it does not seem stiff in conveying. Student participation in classroom learning is also increasing. It's just that some students seem to lack confidence in asking questions in other groups (doing anger). Some students also find it difficult to read a friend's writing while carrying out an activity. Students 'confusion in reading friends' writing is one of the factors that causes the class to become noisy. At the first meeting the division of worksheets along with group numbers in groups were given one by one to the group representatives, but in this second meeting the student worksheets and arm numbers were placed in front of the class for each group representative to take according to the group. This is done so that time is more 
effective and efficient. The time allocation for discussion and the process of reasoning at this 2nd meeting is in accordance with the time specified. In this second meeting students who have negative activities can be seen among them being disrespectful student behavior when students sit in the classroom by raising their feet in a chair. Another negative activity, namely students wearing hats in class at the beginning of learning is ongoing. The students who asked permission to leave the room there were 3 students

The third meeting, class conditions are very good/conducive for learning. Classes are no longer noisy, but far more orderly. Students show confidence in asking questions to other groups (doing anger). Students look more excited. The division of student worksheets (student worksheets) along with the number of the arm is done by the teacher by doing it in front of the class and then each group representative simultaneously takes it in accordance with the group. The time allocation for discussion and the process of reasoning at this 3rd meeting is in accordance with the time specified. In this meeting III students who have negative activity, that is, only a student asks permission to leave the room.

Based on the results of observations during the first cycle, it can be stated that in the beginning learning had not yet run conducively and gradually became more conducive. Changes in students' attitudes and behaviors during cycle 1 (1st meeting at 3rd) show better changes. The motivation for student learning in learning is slowly becoming more visible. Motivation or encouragement needs to be done so that students' interest in learning can be increased. Motivation is the overall driving force in students that causes learning activities, guarantees the continuity of teaching and learning activities, and gives direction to learning activities to achieve goals (Winkel, 1991). The attitude of students in learning can be influenced by feelings of pleasure or displeasure at the teacher's appearance, lessons, or the surrounding environment. Teachers must try to be teachers who are responsible and professional so that negative attitudes in learning do not arise.

Students who do not have an interest in learning, will not be enthusiastic or even unwilling to learn. The teacher needs to arouse the interest of students so that they are interested in the material they are learning. Teachers can arouse interest in learning by making the material learned as attractive as possible and not boring, both from learning design that allows students to explore what is learned, involving cognitive, affective, and psychomotor students so students become active, as well as interesting teacher performance in teaching.

Students who do not have an interest in learning, will not be enthusiastic or even unwilling to learn. The teacher needs to arouse the interest of students so that they are interested in the material they are learning. Teachers can arouse interest in learning by making the material learned as attractive as possible and not boring, both from learning design that allows students to explore what is learned, involving cognitive, affective, and psychomotor students so students become active, as well as interesting teacher performance in teaching.

Teachers play an important role in learning activities, in creating an environment that supports student learning activities, so that they feel able to overcome their problems and feel valued. Cooperative group work can help improve calm, positive attitudes and understanding of his work and himself. The benefits of cooperative group work activities, can be obtained with students given the opportunity to develop various skills, all students have equal opportunities in the learning process. 
52| Jurnal Ilmiah Ilmu Administrasi Publik: Jurnal Pemikiran dan Penelitian Administrasi Publik

Volume 9 Number 1, January - June 2019. Page 37-56

Cooperative learning occurs when students share responsibility for achieving common goals. The development of cooperative working skills in groups includes appropriate time, practice, and warning behavior and is expected to create an atmosphere of mutual cooperation in learning, so that students who have high learning outcomes can help other students who have low learning outcomes or in other words smarter students being a guide or tutor from less intelligent students. In order for the implementation of cooperative learning to run well, the efforts that must be made include, that is, the teacher always learns the techniques of applying cooperative learning models in the classroom and adapts to the material to be taught. In this learning the teacher applies a cultural model in an effort to apply the implementation of cooperative learning to run well.

In this first cycle, in addition to changes in student behavior, there was also a change in the attitude and behavior of the teacher in managing learning. The teacher strives to improve in creating an environment that supports student learning activities. The teacher changes the way the LKS is distributed and the number of the arm. At the first meeting the division of worksheets (student worksheets) along with group numbers in groups were given one by one to group representatives, but in the second meeting and so on, the student worksheets and arm numbers were placed in front of the class for each group representative to take according to the group . This is done so that time is more effective and efficient. In addition, the teacher can also arouse the interest of students to be interested in the material they are learning, using a culturebased model. The teacher can make the material learned as attractive as possible and not boring. This is because the design of learning allows students to explore what is learned, involving cognitive, affective, and psychomotor students so students become active.

The fourth and fifth meeting is the second cycle. The fourth meeting, the learning conditions of students are good. Students learn more relaxed and more freely in the outdoors. The activities of students by carrying out groups to other groups are more flexible and free because they are not blocked by tables and chairs. Nevertheless the concentration of learning students is interrupted occasionally by the conditions that occur around the place of learning. The role of the teacher is needed in minimizing the attention of students to stay focused on learning. No student has permission to go to the bathroom during the learning process, and student learning activities are also relatively good.

The fifth meeting, student learning activities improve. Student cooperation is increasingly visible in group work. The courage of students in expressing opinions is also increasingly evenly owned by students. Outdoor learning is perfect for refreshing the learning atmosphere in the final hours of learning, because students can learn more relaxed and comfortable in the cool breeze. Students' activities by carrying out their experiences to other groups are more flexible and are not blocked by tables and chairs. The concentration of student learning during learning takes place is maintained. No student has permission to go to the bathroom during the learning process, and student learning activities are also relatively good.

The physical condition of students who are healthy and fit will have a positive influence on student learning activities. The teacher has the initiative to do outdoor learning in order to provide a refreshing learning environment for students. The classroom atmosphere in the final hours of learning was very hot and the physical condition and concentration of students had also declined, while students were bored in the classroom. This is in accordance with the opinion of 
Herzberg Scientists (in Akhmad Sudrajat, 2008) who put forward the "Two Factor Model" of motivation, namely motivational factors and hygiene or "maintenance" factors. Student motivational factors include the success of learning achieved, the opportunity to grow, progress in learning, and recognition from others. Student hygiene factors include good, intimate, and harmonious relationships between students and teachers and between students in the classroom. Presents or rewards for students who carry out positive activities in learning will give rise to extrinsic motivation from students. Learning with a culture-based model has been able to create good, intimate, and harmonious relationships between students and teachers and between students in learning. Praise in the form of clapping hands, score scores for students who carry out positive activities can also lead to motivation for students.

In the first cycle the highest to lowest learning activities of students, is cooperation in carrying out tasks (3.20), courage to think (2.95), participation (2.87), and student attention during learning (2.83). Values in the cycle indicate that learning activities that occur are good learning activities, because they range in value from 2.5 to 3.4. In Cycle II the scores of student learning activities from the highest to the lowest were students' attention during learning (3.38), cooperation in carrying out tasks (3.34), participation (3.22), and courage to think (3.14). The value of the activity cycle II score is good for each component of activity, because it ranges in the range of values $(2.5-3.4)$.

Student learning activities from cycle I to cycle II have increased values but are still in the same value category, which is good. Student learning activities which include; students' attention during learning, cooperation in carrying out tasks, participation and courage argue in a range of values (2.5 - 3.4) so that it is of good value. Learning activities in the form of student attention during learning in the second cycle occupy the highest value in the observed component, where in the first cycle shows the lowest value sequence. This shows that learning occurs pleasantly, and student learning motivation increases. Overall learning activities that occur, both cycles I and II are good learning activities.

The learning outcomes of class VIIA students with $73 \mathrm{KKM}$, in the first cycle showed 7 people (24.1\%) were not completed and 22 people (75.9\%) were completed from 29 students. While the learning outcomes of class VIIA students in the second cycle showed that 4 people (13.4\%) did not complete and 25 people (86.2\%) completed from 29 students. Changes regarding student learning outcomes also occur in this learning, namely the percentage of students' mastery learning which increased from $75.9 \%$ to $86.2 \%$.

Data obtained based on student questionnaires at the end of the first cycle showed that students stated Strongly Agree (SS) on the statement given at (55\%), Agree (S) (40\%), Doubt (R) $(4.14 \%)$, Disagree (TS) $(0.34 \%)$, and Strongly Disagree (STS) $(0.34 \%)$. Based on the data above, it can also be said that the students of class VIIA during the first cycle enjoyed the PPKn lessons and showed enthusiasm for learning in the PPKn subjects. This is shown in the SS and S statement values in the questionnaire which reached (95\%), R (4.14\%) and the rest of TS and STS did not reach (1\%).

Changes in behavior and attitudes of students as well as teacher I occurred in this second cycle. Students are more excited and comfortable in learning. The teacher chooses the right place of learning changes for students' comfort in learning in the final hours of learning. Of course, it is inseparable from the efforts of the teacher to create a pleasant and intimate learning atmosphere so that students' attention during learning will be maintained. 
54| Jurnal Ilmiah Ilmu Administrasi Publik: Jurnal Pemikiran dan Penelitian Administrasi Publik Volume 9 Number 1, January - June 2019. Page 37-56

\section{CONCLUSION}

Based on the analysis and discussion of this study, it can be concluded that the cultural model of berasanan and its implementation in Civics learning can increase Civics learning motivation in class VII A of Indralaya 2 Public Middle School.

\section{REFERENCES}

Amaliyah, R., Akib, H., \& Tambe, M. N. (2015). Pengaruh Metode Mengajar Bervariasi Guru Terhadap Motivasi Belajar Siswa Pada Jurusan Administrasi Perkantoran Smk Negeri 1 Makassar. Jurnal Office, 1(2), 198-205.

Chiang, T. H.-C., Yang, S. J. H., \& Hwang, G.-J. (2014). An augmented reality-based mobile learning system to improve students' learning achievements and motivations in natural science inquiry activities. Educational Technology \& Society, 17(4), 352-365.

Cooley, J. H., \& Larson, S. (2018). Promoting a growth mindset in pharmacy educators and students. Currents in Pharmacy Teaching and Learning, 10(6), 675-679. https://doi.org/https://doi.org/10.1016/j.cptl.2018.03.021

Dewi, S. R., \& Arifin, A. (2016). Perbandingan Hasil Belajar Pendidikan Agama Islam Melalui Model Pembelajaran Kooperatif Tipe Teams Games Tournament (Tgt) Dan Tipe Jigsaw Pada Siswa Kelas X Di SMA Negeri 2 Wakorumba Selatan Kabupaten Muna. Al-Ta'dib, 9(2), 1-21.

Fajri, N., Yoesoef, A., \& Nur, M. (2017). Pengaruh Model Pembelajaran Kooperatif Tipe Talking Stick Dengan Strategi Joyful Learning Terhadap Prestasi Belajar Siswa Pada Mata Pelajaran IPS Kelas VII MTsN Meuraxa Banda Aceh. Jurnal Ilmiah Mahasiswa Jurusan Pendidikan Sejarah, 1(1).

Healy, K., \& Healy, K. (2016). A Theory of Human Motivation by Abraham H. Maslow (1942) A Theory of Human Motivation by Abraham H. Maslow- reflection References.

Herzberg, F. (2017). Motivation to work. Routledge.

Idzhar, A. (2016). Peranan Guru dalam Meningkatkan Motivasi Belajar Siswa. Jurnal Office, 2(2), 221-228.

Ismail, M. A. (2013). The relationship between motivations and self-learning and the English language achievement in secondary high school students. Asian Social Science, 9(12), 36.

Isnawati, N., \& Setyorini, D. (2012). Pengaruh Perhatian Orang Tua dan Motivasi Belajar Siswa terhadap Prestasi Belajar Akuntansi pada Kompetensi Mengelola Dokumen Transaksi Siswa Kelas X Program Keahlian Akuntansi SMK Cokroaminoto 1 Banjarnegara Tahun Ajaran 2011/2012. Jurnal Pendidikan Akuntansi Indonesia, 10(1).

Kamaluddin, L. O. A., Haerul, H., Akib, H., \& Salam, R. (2018). Analysis Of Factors Influencing Student Learning Achievement.

Mihrez, A.-A. H. E., \& Thoyib, A. (2015). The Importance of Leadership Behavior and Motivation In Creating Employee Performance:(A Study at the Faculty of Economics and Business, University of Brawijaya). Asia-Pacific Management and Business Application, $3(2), 86-105$.

Niswaty, R., \& Darwis, M. (2015). Pengaruh Komunikasi Interpersonal Pimpinan Terhadap 
Motivasi Kerja Pegawai Pada Kantor Dinas Perindustrian Dan Perdagangan Di Kabupaten Sinjai. Jurnal Office, 1(1), 38-47.

Novelti, N., Ramadhan, S., Ermanto, E., \& Agustina, A. (2018). Developing an Instructional Model Assisted Audio Visual Media. International Conference on Language, Literature, and Education (ICLLE 2018). Atlantis Press.

Puente-Díaz, R., \& Cavazos-Arroyo, J. (2017). The influence of creative mindsets on achievement goals, enjoyment, creative self-efficacy and performance among business students. Thinking Skills and Creativity, 24, 1-11. https://doi.org/https://doi.org/10.1016/j.tsc.2017.02.007

Saggaf, M. S., Nasriyah, N., Salam, R., \& Wirawan, H. (2018). The Influence of Teacher's Pedagogic Competence on Learning Motivation of Student of Office Administration Expertise Package.

Saggaf, M. S., Salam, R., \& Rifka, R. (2017). The Effect of Classroom Management on Student Learning Outcomes. International Conference on Education, Science, Art and Technology, 98-102.

Salam, R., Akib, H., \& Daraba, D. (2018). Utilization of Learning Media In Motivating Student Learning. 1st International Conference on Social Sciences (ICSS 2018). Atlantis Press.

Sanjaya, D. R. H. W. (2016). Penelitian tindakan kelas. Prenada Media.

Stamboulis, Y., \& Barlas, A. (2014). Entrepreneurship education impact on student attitudes. The International Journal of Management Education, 12(3), 365-373. https://doi.org/https://doi.org/10.1016/j.ijme.2014.07.001

Tang, M., Werner, C., \& Karwowski, M. (2016). Differences in creative mindset between Germany and Poland: The mediating effect of individualism and collectivism. Thinking Skills and Creativity, 21, 31-40. https://doi.org/https://doi.org/10.1016/j.tsc.2016.05.004

Utari, R. D. (2018). Model Pembelajaran Kooperatiif untuk meningkatkan minat belajar peserta didik di MI Muhammadiyah 3 Penatarsewu. Universitas Muhammadiyah Sidoarjo.

Vibulphol, J. (2016). Students' Motivation and Learning and Teachers' Motivational Strategies in English Classrooms in Thailand. English Language Teaching, 9(4), 64-75. 
56 Jurnal Ilmiah Ilmu Administrasi Publik: Jurnal Pemikiran dan Penelitian Administrasi Publik Volume 9 Number 1, January - June 2019. Page 37-56 